\title{
Industrious, but Formal and Mechanical: The Sisters of Charity of Providence in Residential School Classrooms
}

\author{
Brian Titley \\ University of Lethbridge
}

\begin{abstract}
During the 1940s and 1950s the classrooms at St. Martin's (Wabasca) and St. Bruno's (Joussard) residential schools for First Nations' children in northern Alberta were staffed by the Sisters of Charity of Providence, a religious community that specialized in caring for the sick and the elderly. In this essay the effectiveness of the sisters as teachers is examined in the context of a missionary/reformatory model of schooling that was rapidly falling into disfavour. A picture emerges of a hard-working group of women whose lack of education and teacher training hampered their ability to meet the needs of their students.
\end{abstract}

\section{RÉSUMÉ}

Pendant les années 1940 et 1950, le personnel des pensionnats autochtones de Saint-Martin (Wabasca) et de Saint-Bruno (Joussard) dans le nord de l'Alberta provenait de la communauté des Sœurs de la Charité de la Providence, un ordre religieux spécialisé en soins aux malades et aux personnes âgées. Cet article étudie l'efficacité des sœurs enseignantes, dans le contexte d'un modèle d'instruction, celui de missionnaires chargées d'écoles de réforme, modèle qui tombait alors en désuétude. De cette analyse, il ressort un portrait d'un groupe de travailleuses acharnées qui, par manque d'instruction et de formation pédagogique, n'ont pu répondre aux besoins de leurs élèves.

The true purpose of the schools they (missionaries) established was to process good little Christian boys and girls... Since the Indian was expected to live in isolation from the rest of society, obviously all the education he needed was a bit of reading, writing, figures and some notion of hygiene... In plain words, the system was lousy. The curriculum stank and the teachers were misfits and second raters. 
The harsh judgment of radical Aboriginal leader Harold Cardinal on the segregated school system conducted for his people still resonates more than 40 years after it was written. Cardinal's view is a useful point of departure since, inter alia, he received his early education at St. Bruno's Residential School, Joussard, Alberta, one of the institutions to be examined in this paper. His book, The Unjust Society, was a polemic, but a much-needed one at the time, and his strident rhetoric must be interpreted in the context of his campaign to rally public opinion against the ill-considered policies of the Trudeau government. ${ }^{2}$ The schools he condemned, and particularly those that were residential, have been the subject of much scholarly investigation in the intervening years, ${ }^{3}$ and the experiences of many former students have been recorded in published memoirs and official inquiries. ${ }^{4}$ His claim that the system was "lousy" is difficult to dispute in the light of this literature, but what of his assertion that the teachers were "misfits and second raters"? The literature is less helpful on this question. While there is much evidence of brutality and abuse by residential school personnel, we know little of their effectiveness as classroom instructors. My concern in this paper is with the work of a Roman Catholic congregation of women religious (nuns) that staffed two schools in northern Alberta with personnel who were mainly unqualified for the job. A brief discussion of the residential school context and the question of teaching credentials is necessary before proceeding to the central concern.

Residential schools have attracted much publicity and even an apology by the government of Canada for its failure to address systemic abuses. Yet they never enrolled a majority of eligible Aboriginal children. They were located mainly in the western provinces and in the north where a more intensive approach to cultural assimilation was considered necessary. ${ }^{5}$ Joint ventures between the federal Indian Department and the major Christian churches, they provided a program of basic literacy, manual training and religion designed to produce a disciplined class of cheap unskilled and semi-skilled labour to fit the seasonal employment patterns of some sectors of the modernizing economy. It was a segregated model that bore little resemblance to the public schools attended by most non-Aboriginal Canadians and was similar to the industrial and reformatory school systems in which neglected and delinquent youth were incarcerated. ${ }^{6}$

Early in the twentieth century some Protestant missionary leaders began to question the enterprise of residential schooling. It was expensive, results were meager and there was a growing sense that the entire matter should be left to the government. ${ }^{7}$ But the Roman Catholics, who managed two-thirds of the schools, had no such doubts. The Oblates of Mary Immaculate, a religious order originating in France in the early nineteenth century and the principal missionary body working on reserves, continued to support residential schooling. The Oblates feared that any change in the status quo would result in a loss of state subsidies and a consequent weakening of their missions and influence in Aboriginal communities. And they resisted any attempt by the state to regulate their educational work. ${ }^{8}$

The question of teacher certification/qualifications was one potentially troublesome area of state intervention. In the loose and unregulated contractual arrangements 
that prevailed before World War II the missionary churches were free to hire whomever they wanted to work in the residential schools under their management. The typical Catholic school was under the direction of an Oblate priest who held the title of principal. As a general rule the principal did not teach nor provide much guidance on educational matters. He was responsible for the entire residential operation, and for all correspondence with governmental and ecclesiastical bodies, but his authority rested on his standing as a missionary priest, rather than his role of educator. The title "principal" was really a misnomer and the job never required any academic or professional qualifications. ${ }^{\text {? }}$

Classroom instruction (the academic program) was usually in the hands of congregations of religious sisters. Many of the sisters were untrained as teachers but the Church took the view that their commitment to the religious life was a superior qualification to a teaching certificate issued by the state.${ }^{10}$ And since the Church gave priority to the evangelical rather than to the educational purposes of the schools, its reasoning on this matter can more readily be understood.

By the onset of the Second World War the federal Indian Department, ${ }^{11}$ which was ultimately responsible for the system, questioned the status quo on a number of accounts: the effectiveness of the residential experience, the quality of the instructional program, the value for money that was being provided, and the virtual carte blanche given to the churches in management. In 1940, C. Pant. Schmidt, inspector of Indian agencies in Alberta, reported on several conversations he had had with religious authorities regarding the practice of employing unqualified nuns as teachers while there were "scores of qualified teachers of both sexes and all creeds" looking for work. ${ }^{12}$

R.F. Davey, who served as the Indian Department's Director of Education for much of the 1950s and 1960s, recalled visiting residential schools in the 1940s and being dismayed to find classrooms of over 60 students who received academic instruction for only half a day. The remainder of the day was given over to manual labour. Davey was not surprised that very few aboriginal youth made it into high school. He noted that in 1945 there were just over 100 students across the country in Grades 8 and 9, and nobody beyond that level. ${ }^{13}$

Aboriginal spokespersons were also highly critical. The Rev. Edward Ahenakew, a Cree university graduate, argued in the 1930s for schools with the best teachers, rather than those "who seldom have any qualifications to teach." Similarly, the League of Indians of Western Canada demanded that students spend more time in the classroom with properly qualified teachers. ${ }^{14}$

The Indian Department was increasingly sensitive to what appeared to be a growing body of criticism of its educational provision for First Nations children - especially if the criticism came from knowledgeable sources. Provincial school officials were one such source, since they were often hired by the understaffed Department to inspect its schools. The results could be discouraging. For example, in August 1946 a group of Alberta school superintendents who had visited federal schools, met to discuss their impressions. They concluded that the curriculum and quality of instruction were inferior to those found in provincial schools due to lack of proper 
supervision and a shortage of qualified teachers. ${ }^{15}$

The Special Joint Committee of the Senate and House of Commons that examined Indian policy between 1946 and 1948 recommended that federal day and residential schools be closed and their students transferred to public schools under provincial jurisdiction. It was admitted that the original goal of producing a generation of Aboriginal children who were well educated, culturally transformed and integrated into the mainstream had not been realized. And even before the residential schools could be closed down, it was recommended that their more objectionable features be eliminated. In 1951 rules requiring full-time academic study were introduced bringing an end to the practice of dividing the day between study and manual work. Farming operations came to an end and the daily routine borrowed from nineteenth century reformatory institutions faded. ${ }^{16}$

It was a step in the right direction, but Department officials and many Aboriginal parents were well aware that the weaknesses in the academic program were largely attributable to "deficiencies in the teaching staff." A Department survey completed in the Fall 1952 showed the enormous range of academic credentials held by those responsible for classroom instruction in Roman Catholic residential schools. There were 198 teachers in all, 119 of whom held teaching certificates, and 79 of whom did not. Among the qualified teachers, 61 held second-class certificates, 52 held first class certificates and 6 had qualifications superior to those required for a certificate. The uncertified had the following educational attainments: ${ }^{17}$

University degrees: . . . . . . . . . . . . . 6

Some university work: . . . . . . 6

High school graduation: . . . . . . . 21

Partial high school completion:. . . . . 37

No high school studies:. . . . . . . . . 10

On 1 September 1954 the government took responsibility for the direct payment of teachers' salaries in church-managed residential schools. ${ }^{18}$ Prior to that teachers had been paid by church authorities from government grants based on per capita enrolment. The new arrangement relieved school management of some financial constraints but it did not interfere with management's right to select its own instructional staff. For Catholic managers the requirement that teachers be Catholic, and preferably in religious vows, continued to be a more important consideration that possession of a teaching certificate.

The problem of unqualified religious teachers was one of several shortcomings observed in a major study of First Nations' educational needs conducted on behalf of the Indian Department by C.G. Brown, G.J. Buck and B.O. Filteau in 1956. Brown et al. pointed out that in a large number of residential schools the teaching and supervisory personnel had a very poor command of English (mainly a Catholic francophone phenomenon) with the consequence that students were learning a broken and imperfect version of the language. They suggested that more lay teachers, especially qualified ones, would improve the situation. The schools needed effective leadership in matters of administration, teaching, testing, evaluation and so forth, 
something that could not happen while principals were in fact missionary priests with no educational qualifications. ${ }^{19}$

In 1957 the Department's school inspector in British Columbia pointed to another problem peculiar to Catholic residential schools. He complained of the difficulty of recruiting and retaining able teachers because of lack of career advancement in institutions where most administrative positions were held by those in religious vows. ${ }^{20}$

Resolving the problem of unqualified teachers was not easy, especially since qualified teachers were in great demand in the rapidly expanding provincial school systems of the day. ${ }^{21}$ Nevertheless, the problem was compounded by the Department's failure to exercise its authority to refuse nominations to residential school teaching positions. When the missionary principal was nominated, the Department invariably accepted the recommendation, even if it had reservations about the nominee. This was particularly troublesome in circumstances where the Church preferred unqualified nuns to qualified lay people.

Situations of this sort existed in Alberta where no less than eight different religious congregations of nuns staffed schools in partnership with the Department. Some of the congregations had good records in providing qualified personnel. This was the case, for instance, with the Dominican Missionaries Adoratrices who in 1962 staffed two day schools with nuns who were all certified teachers. It was the same with the Sisters of St. Cretienne and the Sisters of Wisdom who staffed one day school each.

Congregations that staffed larger institutions were not quite as committed to the notion of full qualifications. The Grey Nuns ( 4 schools) and the Sisters of the Assumption ( 2 schools) averaged around 80 percent qualified teachers. But the worst record in providing qualified teachers belonged to the Sisters of Charity of Providence who staffed five residential schools (St. Martin's, St. Bruno's, Fort Vermilion, Crowfoot and Assumption). Of the 12 nuns thus employed, 5 (41.7 percent) were qualified and 7 (58.3 percent) unqualified. The Indian Department was willing to urge them to strive for full qualifications, but beyond that it was not prepared to go. ${ }^{22}$

The Sisters of Charity of Providence, it has been noted, had the worst record among female religious congregations in Alberta in the matter of staffing classrooms with qualified teachers. Two of their schools, St. Martin's at Wabasca and St. Bruno's at Joussard, serve as case studies for the examination of this phenomenon. These were residential schools established for the Woodland Crees who had signed Treaty 8 in 1899. What were the educational consequences for students in these schools of being taught by unqualified nuns? Why did such an arrangement endure for so long when its shortcomings were evident for many years?

The Sisters of Charity of Providence were founded in Montreal in March 1843 by Bishop Ignace Bourget and Madame Emilie Tavernier (Gamelin), a pious widow with a strong interest in the welfare of the unfortunate. The congregation was inspired by the example of the Sisters of Charity of St. Vincent de Paul, and its primary mission was to care for the sick, poor, and elderly. Hospitals, refuges, asylums and orphanages were the institutions most often associated with these sisters, rather than schools. ${ }^{23}$ In 1893 Bishop Emile Grouard asked the congregation to send sisters to 
his vicariate in the North-West Territories to work with the Oblate Fathers in establishing and operating residential schools for Aboriginal children. The request was unusual, since learning to teach was not part of the regular formation of the sisters. Nonetheless, Mother Marie-Godefroy, the superior general, accepted the invitation and individual sisters, following their vows of obedience, took up the challenge of the residential school classroom. ${ }^{24}$

In examining the work of the Sisters of Charity of Providence at St. Martin's and St. Bruno's, I rely mainly on the detailed inspections carried out annually on the schools between 1945 and 1957..$^{25}$ Some inspections were done by L.P.G. Waller, the Department's regional inspector for Alberta. Most of this work, however, was in the hands of officials with provincial school boards who were contracted to do it. The officials in question were L. Broughton, Gerald L. Berry and E.C. Stehelin.

\section{St. Martin's (Wabasca/Desmarais)}

St. Martin's School was established in 1920 on the north end of South Wabasca Lake. A three-storey frame building over a basement housed the dormitories, kitchen and classrooms. There were also stables, a warehouse, a mission house and a small farm of 50 acres carved out of the bush. Mother Bernard du Sacre-Coeur, superior general of the Providence congregation, toured the west in the early 1920s and noted the physical hardship endured by the sisters in Wabasca. Financial dependence on the Oblate Fathers was a major part of the problem. ${ }^{26}$ By the 1950 s the main building was in deteriorating condition, swayed in the wind, and was unevenly heated in winter by four wood-burning units. The classrooms were considered unsatisfactory with oldfashioned furnishings and pillars that obstructed the view of the blackboard. ${ }^{27}$

When Indian Affairs inspector L.P.G. Waller visited the school in 1952, he was unimpressed, as the following excerpt from his report indicates:

The school program is not as vigorous and purposeful as one would wish and consequently is not making the progress one might expect. The general response to school work lacks spirit, possibly because the children see very little reason for attending school.

To remedy these deficiencies, he proposed the cultivation of better relations between school and community, the establishment of sports and manual training programs, and the employment of qualified teachers. ${ }^{28}$ Not much was done to implement these proposals in the decade that followed.

Part of the difficulty in bringing about change was the arrangement whereby classroom instruction lay exclusively in the hands of the Sisters of Charity of Providence. Between 1945 and 1952 the same three nuns did all the teaching at St. Martin's. The advantage of continuity thus provided was undermined by the fact that only one out of three had studied to be a teacher and held a certificate. Let's examine their work in some detail.

Sister Mary Stella (born Hilda Diedrich in 1893) was a high school graduate, had 
completed a two-year teacher education course in Spokane, Washington, and held a second-class Alberta certificate. In spite of her advancing age, she was described as energetic, intellectually alert, confident and spirited in her work. Inspectors praised her grasp of teaching methods and her willingness to try out new ideas in accordance with Alberta curriculum requirements. Students were participating actively, responding willingly and intelligently and were making suitable progress. Mary Stella was responsible for the beginners and Grade 1 and was clearly doing a good job, although struggling at times with large enrolments. In 1951, for example, she had no less than 38 students in her class. ${ }^{29}$

Sister Mary Bernadette (Frances Mulvihill) was in charge of the senior students (Grades 4,5,6). She had no teacher training and had only completed Grade 8 of formal education herself. Her energy and enthusiasm carried her a long way but her lack of training showed in her formalistic style of instruction with an emphasis on mastery of text materials. Inspector Broughton described her classroom in 1949 as having a "restricted, teacher-dominated atmosphere." Nonetheless, she was presenting a "worthwhile program" and student progress was "relatively satisfactory." When the inspector observed Mary Bernadette again in 1952 he commended her on her well-designed lesson plans and on her willingness to try out more modern teaching methods. ${ }^{30}$

Sister Helen of the Crucifix (born Edna Garand in 1899) was clearly the weakest staff member and her performance in the classroom was a source of concern to every inspector who observed her teaching during her lengthy career. She had no training as a teacher and, like Sister Mary Bernadette, had only completed Grade 8 of formal education. Moreover, her command of English was described as "fairly good" and she did not have much natural aptitude for teaching. She had spent some years teaching in Ft. Vermilion and Joussard before taking up her post in St. Martins's in 1931 where she was responsible for Grades 2 and 3. Her years of experience had given her a good sense of classroom organization but her teaching methods were mechanical, reliant on rote memorization, and dull. Discipline was good but she did not encourage student initiative. Lots of time was spent copying material into books, a method that at most produced some good examples of cursive writing. Inspector Berry observed that students seemed bored with the childish reading materials they were assigned. He suggested the use of high interest books with low vocabulary. He noted that achievement in art and singing was good. And students had a solid grasp of the basics of addition, but were weak in other arithmetic procedures.

Berry was exasperated by Sister Helen's “very limited conception of teaching procedures" and the predictable sameness of her classroom year after year. During his inspection of 1955 he noted that she had no less than 46 students in her classroom, 27 of whom were between the ages of 12 and 14 . While recognizing the difficulty of such a teaching situation, he felt compelled to note: "It seems rather silly to have big fourteen-year old lads repeating in a dull voice the days of the week, little nursery jingles, and other similarly innocuous material." A year later Berry reported that nothing had changed, commenting that Sister Helen remained attached to teachers' guidebooks long out of date, one of which bore the date $1922 .{ }^{31}$ 
When Sister Mary Stella left or retired in 1952, another qualified teacher, Sister Theresa (Catherine McIntyre) was placed on staff. She was the only certified teacher at St. Martin's until her departure in 1956. Sister Theresa had joined the Sisters of Charity of Providence in 1934 expecting to work with the elderly. But in 1936, with her religious studies completed, she was sent to St. Martin's to take up a teaching post she neither wanted nor was qualified for. The decision was made for her by the provincial of the congregation and, in accordance with her vow of obedience, she did what was required of her. Later she was able to complete a B.A. in Seattle and receive teacher training in Calgary. When she returned to St. Martin's in 1952 she felt that the students were behind in achievement compared to those in Grouard, where she had been teaching. She felt that students were not that interested in school but she hoped to do something about it. But she began to realize that without qualified teachers and staff, it might not be possible. ${ }^{32}$

Sister Theresa took the senior grades $(5,6,7$, and later 8$)$ and by all accounts did a competent job. Although her classroom was cold and drafty in winter, it was well equipped and decorated. She exercised firm control over her students, employed good teaching techniques and tried to make learning relevant to her students. Progress in English and arithmetic was reasonably good. ${ }^{33}$

Theresa, who held to title Sister Superior, was hampered in her efforts to advance the academic program by an unqualified teaching staff. There was some staff turnover during those years but every nun who took charge of a classroom whether for a long or short period, except for Sister Theresa, was unqualified.

Sister Anne Theresa, who only remained a year, was described as far from robust and lacking the confidence that would have come with training. Sister Celine (Frances Peach) who only had a Grade 10 education, had a natural talent for teaching that enabled her to do satisfactory work. Sister Kilean (born 1896 in Ireland) had a Grade 11 education and her many years of experience gave her a good command of the classroom. Sister Elaine Margaret was untrained, but her energy and confidence allowed her to do solid work marred by a tendency to employ mechanical methods that encouraged memorization. Sister Benigna of the Sacred Heart was also untrained, but was confident, had good relations with students and was able to diagnose learning problems and take remedial action. But she too was attached to drill, rote learning and ritualistic reproduction. ${ }^{34}$ These portraits show a group of hard-working women, many with a natural flair for teaching, who probably could have done excellent work in the classroom had they been permitted to pursue a program of teacher education.

During the first half of the 1950s enrolment at St. Martin's grew steadily from 100 students in 1951 to 145 in 1955 . With only three teachers, it also meant increasing class size. This problem was alleviated somewhat in 1955 with the appointment of a fourth teacher. But it now meant that only one teacher (St. Theresa) out of four was qualified.

By 1957 Theresa was gone but two new certified teachers arrived to join Elaine Margaret and Benigna of the Sacred Heart. The new arrivals were Sisters Marie Rustica (Yvonne Gerard) and Eulalia (Georgina Desjardins). The first had a good 
grasp of curriculum and gave careful guidance to students. Her lessons tended to be formal, but she had clever ideas to maintain interest. The latter, in spite of her certificate, lacked enthusiasm and imagination and was hampered by lack of clarity of expression. Her lessons were dull and failed to maintain student interest. ${ }^{35}$ Sometimes teacher training could make little difference, especially when an aptitude for the job was missing.

Inspectors had noted over the years that St. Martin's was a reasonably well equipped school as far as audio visual aids and books were concerned — although the books often seemed unsuitable. They complained of poorly/designed classrooms that were cold and poorly lit. A fire-escape blocked light coming in some of the windows and the principal liked to use 30-watt bulbs to save on energy. When Inspector Berry was critical of this in 1953, the principal put in 60-watt bulbs but wouldn't go for the 100 -watt variety lest they place too many demands on the electricity-generating plant. ${ }^{36}$ The problem of cold and poorly-lit classrooms was not resolved until completion of a new classroom block in $1959 .{ }^{37}$

The appointment of a fourth teacher in 1955 only partly solved the problem of overcrowded classrooms. There was no repeat of a classroom enrolment of 49 , which happened in 1954, but in every year afterwards for which there are figures, at least one classroom contained over 40 students.

With a preponderance of uncertified teachers, cold, poorly-lit and over-crowded classrooms, it would be difficult to make the case that education in St. Martin's in the 1940s and 1950s amounted to a quality experience. The assessment of Indian Affairs inspector L. Jampolsky in 1960 was not encouraging. He noted that classroom enrolments were "exceptionally heavy," and that teacher staff were "relatively weak." The mother superior held an Alberta certificate and one other had a Saskatchewan interim certificate. The three other teachers were unqualified. Pupil achievement was "far below that which may be expected." ${ }^{38}$ The school closed in 1973.

\section{St. Bruno's (Joussard)}

St. Bruno's Residential School at Joussard was built between 1912 and $1914 .{ }^{39}$ It was similar to St. Martin's in that it was managed by the Oblate Fathers and employed the services of the Sisters of Charity of Providence as classroom teachers. The original school building at Joussard had burned down and was replaced by a new one in 1929 and was still in good condition by the 1950s. A fine gymnasium was built in 1952 . Visitors in the post-war period commented on the effectiveness of the industrial arts program and on the solid furniture the boys who took the program had made. ${ }^{40}$

The academic program suffered from the reluctance of the Sisters of Charity of Providence to provide qualified teachers. In any given year between 1945 and 1952, of the four nuns engaged in classroom teaching, only one was qualified to do so. The qualified teacher was Sister Mary Thecla (born Regina Beaudry on 21 August 1892) who held a second class certificate and who served as senior teacher at the school almost continuously from 1945 until at least 1956. Her teaching style was of the old school, with much use of drill, rote learning and emphasis on the mastery of texts. 
She was mildly authoritarian, could be "somewhat impatient and sharp" with her pupils who were well behaved, but regimented. She was, however, prepared to make some effort at modern teaching methods. Inspectors deemed the progress of her students to be satisfactory. ${ }^{41}$

Her unqualified companions in the other three classrooms performed with varying degrees of competence. Sister Rita Marguerite (Alice Trudeau), who taught the senior grades between 1945 and 1952, had a Grade 10 education from Manitoba. She was industrious, energetic and showed natural ability as a teacher. Her lack of training and general education held her back and her approach to teaching tended to be formal. She was amenable to suggestions for improvement, however, and Inspector Broughton considered her "worth developing." By 1952 Inspector Waller concluded that her lack of training made her unsuitable for the senior grades, which now extended to Grade 8, and she was replaced..$^{42}$ It was on of the rare instances in which an inspector's recommendation was acted upon.

In the case of Sister Alicia (Muriel Downs), inspectors' dissatisfaction made little impression and she remained in charge of the beginners' class until 1955 many years after she was judged unable for the work. Alicia had only three years of high school education, which she had completed in Glasgow in 1913. She was often described as more of a mother than a teacher to her young students. Her lack of proper training gave her a number of bad habits in the classroom. She was inclined to do the work for the students instead of cultivating personal initiative. More attention was given to brighter students and wrong answers were not followed up on. And at times she would discuss students' personal shortcomings in front of them, which had a depressing effect. Her teaching was "uninspired, formal and dull" and she did not move student work forward at an appropriate pace. While some progress was recorded respecting the English language using the word recognition approach, inspectors noted that pronunciation was weak. Students at times appeared restless and inattentive; much more effort should have been demanded of them. The inspectors concluded that a younger, trained teacher would have made progress at double the pace. ${ }^{43}$

Sister Guy (Marie Rose Quirion) was another example (like Sister Rita Marguerite) of a capable and talented woman whose lack of teacher training hampered her success in the classroom. She taught Grades 1 and 2 at St. Bruno's between 1948 and 1952. Vigorous, cheerful and enthusiastic, she approached teaching in a formal manner but was prepared to accept suggestions on how to use a greater variety of instructional approaches. Inspector Broughton observed in 1949 that her students' work was not up to standard, noting that "trained personnel would know how to bring about greater mastery." ${ }^{44}$

A consistent problem with these nuns was their tendency to underestimate the ability of their students which Inspector Stehelin identified as a contributing factor to the prevalence of age-grade retardation. In 1945, in his report on the classroom of Sr. Kilean, he observed: "It is impossible to expect their mental age to develop proportionately to their chronological age unless they are placed and confronted with real problems which will demand the full contributions of all their capacities." ${ }^{45}$ In 1946 he had similar criticisms of Sisters Mary Thecla and Rita Marguerite. On Mary 
Thecla's class he wrote: "The objectives to be attained are not very definite. In most instances these children would be capable of doing a great deal more work." On Sister Rita, he had this to say: "As all teachers in Indian schools, I feel that Sister Rita does not expect enough from these children and that since she is not following any course of studies to direct their ultimate objectives, the work covered is not at the grade level indicated above." ${ }^{46}$

Inspector Stehelin was concerned at the serious age-grade retardation at St. Bruno's which he attributed in part to unchallenging teaching and in part to students entering school after the age of 6. In 1947, in his overall assessment of the school, he noted that there were three 14-year-olds in grade 4, and one in Grade 3; there were three 13-year-olds in grade 4, two in Grade 3, three in Grade 2, and one in Grade 1. Drawing on these and other examples, he concluded:

In views of the high age-grade distribution, one cannot expect that the majority of these pupils will reach a minimum level of achievement before they arrive at school leaving age. By minimum level of achievement is meant sufficient proficiency in language and basic skills so that they will be independent in adult life to carry on individual transactions and correspondence. ${ }^{47}$

Not that the students were incapable. In December 1949 Dr. J. Woodsworth of the High Prairie School Division administered an I.Q. test to the Grades 1 and 2 students at St. Bruno's. He discovered one student with an IQ of 143 and another with 132. In commenting on these results, Indian Affairs District Superintendent G.S. Lapp questioned why very few students from the school made it to Grade 8 in spite of their evident potential. Nor had any passed the Grade 9 provincial exams. He quoted Inspector Broughton who said that Joussard students in Grade 1 and 2 compared favorably to non-Aboriginal students in mental ability. In Lapp's view, residential schools were failing and needed to be replaced by day schools with "competent teachers." 48

St. Bruno's did take a step in a positive direction when it hired Mandy Willier as a classroom teacher in 1954 . Willier was an Aboriginal woman from a nearby reserve and had qualifications just short of eligibility for a teaching certificate. Within a year she had the certificate. She did a fine job in the classroom and her presence improved the morale of the students who were proud to see one of their own in such a position of responsibility. ${ }^{49}$

Willier was the first lay teacher on staff, and she represented the beginning of a trend. By 1960 there were three lay teachers at the school (one of them male), and two nuns. Sister Geraldine of Jesus (Annie Lesoski), had spent a year at the school in 1947 when she was untrained and it is not clear whether or not she became a qualified teacher in the interim. The other nun was Sister Maria Consolata (Cecilia Marino) who held a first class certificate. Maria Consolata assisted the principal, Father F. Sauvé in teaching the 17 students enrolled in Grades 9 and $10 .^{50}$ The trend towards lay teachers was part of the Department's plan to replace unqualified teachers with qualified ones when the former retired. ${ }^{51}$ 
Putting men in charge of classrooms was a belated recognition that nuns had often experienced difficulty in controlling older boys and providing appropriate role models for them. And it was all the more imperative as the Oblates pushed the idea of expanding the school into the high school grades in the $1960 \mathrm{~s}^{52}$ This they succeeded in doing in spite of the Department's reluctance to agree. It was Department policy to integrate senior high students into public schools but they met fierce resistance in the case of St. Bruno's. In 1965 Bishop Henri Routhier, Vicar Apostolic of Grouard, outlined his objections to a proposal to place the school under the jurisdiction of High Prairie School Division. He claimed that with such a move the Church would lose its assurance of Catholic teachers, a Catholic principal and the latitude for religious instruction. He argued that integration was not working and that Aboriginal students were comfortable with the environment in St. Bruno's. ${ }^{53}$

The segregated denominational model survived into the next decade but it was clear that the Department, which several times during the 1960s planned to close it, was reluctant to put adequate resources into an educational institution in which it had lost faith. A report in 1967 showed that the school had high classroom enrolments, no kindergarten and a shortage of qualified teachers. Yet the teachers on staff were dedicated and determined to help their students. ${ }^{54}$ Hard-working teachers handicapped by their lack of qualifications and large classroom enrolments was an all-too-familiar pattern in the history of this school. It closed in 1969.

\section{Conclusion}

During the two decades immediately following the Second World War there was much public commitment in Canada to equality of opportunity - a social ideal enshrined in the massive expansion of public schooling. The baby boom generation enjoyed unprecedented access to education, often in brand new and well-equipped schools. High school graduation became an expectation and was increasingly a requirement for entry into the workforce. "Learn more to earn more" became one of the popular slogans of the day that warned young people of the consequences of "dropping out."And when the generation came of age several new universities and many greatly expanded older ones provided them with further opportunities of study. ${ }^{55}$

In the context of this educational revolution, the schools at Wabasca and Joussard seem strangely anachronistic. They remained essentially missionary in purpose-committed much more to the inculcation of moral discipline and deference to religious authority than to individual achievement and self-fulfillment. Sister Mary James, a Sister of Providence who chronicled some of her congregation's work in the west described the enterprise in typically heroic language:

In northern Canada the aborigines of America give an outlet for a missionary zeal par excellence, and the missionary territory which is the ground of labour offers a particularly ungracious countenance to any but a zealous worker in the vineyard of the Lord. Ice-bound as it is for long months of the year, it offers no 
allurement save that of zeal in the interests of the Master. The work is largely among the Indians, and the industrial and farm schools established among them are carried on with excellent success. ${ }^{56}$

Although the arm of the state (the Indian Department) intruded slowly into their operations, it was a cautious intrusion that generally failed to transform the schools' evangelical nature.

For much of this time St. Martin's and St. Bruno's were under the direction of principals who were missionary priests rather than educators. Classroom teaching was largely in the hands of nuns, many of whom had no training as teachers. Several among the untrained showed great promise as teachers but were never given the opportunity to develop their potential by attending a teacher training course. One consequence was that teaching was often rigid, mechanical and dull and failed to ignite the interest of students. These ineffective approaches, combined with low expectations and high classroom enrolments contributed in large measure to the persistently high age-grade retardation levels in both schools. Most students never made it into the high school levels, which was the norm for non-Aboriginal students.

While this situation was hardly satisfactory, to describe the teachers at Wabasca and Joussard as "misfits and second-raters" in Cardinal's parlance overstates the case. The Sisters of Providence assigned to these classrooms were certainly dedicated and hard working but simply lacked the education, professional preparation and cultural sensitivity to provide meaningful learning experiences for their students.

The Church's reluctance to training its teachers may have stemmed in part from its misgivings concerning the modern teaching methods that were championed strongly in Alberta's faculties of education and by provincial school inspectors. The modern methods were those associated with the progressive education movement and that advocated critical thinking, problem-solving, discovery learning and appealing to the child's interests. ${ }^{57}$ This very approach was denounced by Pope Pius XI in "Divini Illius Magistri," the encyclical on education released in 1929. The Pope attacked progressivism for emphasizing pedagogical methods, pandering to the liberty of the child, undermining the authority of the teacher, and denying that original sin had given humankind "disorderly inclinations" and "evil impulses" requiring correction. ${ }^{58}$

Pius XI's conservatism did not hobble Church policy on education indefinitely. A number of studies conducted in the United States in the 1940s acknowledged with concern that many teaching sisters in Catholic schools lacked proper educational and professional qualifications. ${ }^{59}$ The problem was addressed squarely by Pope Pius XII in July 1951. In a letter to the mothers superior of teaching congregations, the Pope directed that sisters be properly prepared "not only with regard to religious formation but also professional training." He warned that the "pressing requests" of bishops to staff schools might result in a neglect of training but pointed out that only "a properly prepared sister" would be effective, even with small children. ${ }^{60}$ One tangible outcome of Vatican encouragement was the establishment in 1954 of the Sister Formation Movement in the United States. The aim was to improve the general education of nuns, and especially of those who wished to become teachers. ${ }^{61}$ The 
movement spilled over into Canada some years later, although not all congregations embraced it with equal enthusiasm. ${ }^{62}$

Pius XII's desire that teaching sisters have the same mastery of "profane subjects" as their secular colleagues was realized in time but this modernizing tendency did not reach the schools at Wabasca and Joussard in the period under consideration. The Sisters of Providence and the bishops and Oblate Fathers with whom they worked never gave priority to the type of professional training that might have rendered classroom work more effective and meaningful.

The state bears a major responsibility for allowing these schools to continue operating in a segregated missionary mode that was increasingly inadequate to preparing the Aboriginal young to take their places in society. The Indian Department never had the resources to bring the schools to the physical standard expected in the postwar era. Nor did it have the personnel with professional expertise to provide proper supervision of instructional staff or to offer salaries attractive enough to enable it to hire full complements of qualified teachers. And it did not have the political will to insist on reforms when unsatisfactory reports were received. There is little evidence, for instance, that any shortcomings revealed in inspections were acted upon, although they were cited during the 1960s as evidence to phase the schools out.

The schools remained part of the institutional framework of what John Webster Grant called "a sort of missionary half-world that isolated its inhabitants both from Canadian society and from traditional ways." 63 There were some successes, nonetheless. Political activist Harold Cardinal and teacher Mandy Willier come to mind. But they were the exceptions. The modus operandi of St. Bruno's and St. Martin's meant inevitably that Aboriginal talent went undiscovered and undeveloped.

\section{Notes}

1 Harold Cardinal, The Unjust Society: The Tragedy of Canada's Indians (Edmonton: Hurtig, 1969), 53-54.

2 J.R. Miller, Skyscrapers Hide the Heavens: A History of Indian-White Relations in Canada (Toronto: University of Toronto Press, 1989), 230-31.

3 J.R. Miller, Shingwauk's Vision: A History of Native Residential Schools (Toronto: University of Toronto Press, 1996). John S. Milloy, A National Crime: The Canadian Government and the Residential School System, 1879-1986 (Winnipeg: University of Manitoba Press, 1999).

4 Isabelle Knockwood, Out of the Depths: Experiences of Mi'Kmaw Children at the Indian Residential School at Shubenacadie, Nova Scotia (Lockport: Roseway Publishing, 1992).

5 J.R. Miller, "Owen Glendower, Hotspur, and Canadian Indian Policy," in Reflections on Native-Newcomer Relations, ed. J.R. Miller (Toronto: University of Toronto Press, 2004), 118.

6 Brian Titley, The Indian Commissioners: Agents of the State and Indian Policy in Canada's Prairie West, 1873-1932 (Edmonton: University of Alberta Press, 2009), 106-111.

7 John W. Grant, Moon of Wintertime: Missionaries and the Indians of Canada in Encounters since 1534 (Toronto: University of Toronto Press, 1984), 191.

8 Ibid., 198.

9 George Caldwell, Indian Residential School Survey (Ottawa: Canadian Welfare Council, 1967), 115-16. 
10 Thomas O'Donoghue, Come Follow Me and Forsake Temptation: Catholic Schooling and the Recruitment and Retention of Teachers for Religious Orders, 1922-1965 (Bern: Peter Lang, 2004), 129-42.

11 I use this term for the sake of convenience. In 1936 the Department of Indian Affairs became the Indian Affairs Branch of the Department of Mines and Resources. In 1949 the Branch was transferred to the Department of Citizenship and Immigration. And in 1965 it became part of the Department of Northern Affairs and National Resources. In 1966 the Department of Indian Affairs and Northern Development was created.

12 Library and Archives Canada (LAC), RG 10, vol. 205, file 25-1, C. Pant. Schmidt to Secretary IAB. 18 March 1940.

13 Indian and Northern Affairs Canada (INAC), file 601/25-2, vol. 2, Address of R.F. Davey to the Conference of the National Association of Principals and Administrators of Indian Residential Schools, Vancouver, B.C., 8 March 1968.

14 Jean Barman, Yvonne Hébert, and Don McCaskill, eds., Indian Education in Canada, Vol. 1, The Legacy (Vancouver: University of British Columbia Press, 1986), 12.

15 LAC, RG 10, vol. 6015, file 1-1-6-Alta, part 1, "Indian Education in Alberta," Typescript of Alberta school superintendents' meeting, 22 August 1946.

16 INAC file 1/25-1, vol. 35, memo to Mr. Bergeron, 15 Sept. 1969.

17 LAC, RG 10, vol. 8598, file 1/1-13-2, pt.1, R.F. Davey to G. Laviolette, 10 Sept. 1953.

18 LAC, RG 10, vol. 8760, file 901/25-1, pt.2, R.F. Davey to the Director, 14 March 1956.

19 C.G. Brown, G.J. Buck, and B.O. Filteau, Survey of the Educational Facilities and Requirements of the Indians of Canada (Ottawa: Department of Citizenship and Immigration, Indian Affairs Branch, 1956), 13-15.

20 LAC, RG 10, vol. 8614, file 901/1-13, pt.1, A.V. Parminter to IAB, 22 Aug. 1957.

21 Chalmers shows how high standards for Alberta teacher certification were compromised during World War 2 and immediately afterwards. Emergency short training programs were established to deal with the teacher shortage, entrance standards were reduced, and the use of Letters of Authority increased. Even so, there was still an expectation that teachers would take summer courses to learn the basics of their craft and ultimately achieve full qualifications. John W. Chalmers, Schools of the Foothills Province (Toronto: University of Toronto Press for the Alberta Teachers' Association, 1967), 424-25.

22 INAC file 701/1-13, vol. 02/60-02-62, R.F. Davey to G.K. Gooderman, 15 Feb. 1962.

23 Sioban Nelson, "The Harvest that lies before us: Quebec Women Religious Building Health Care in the U.S. Pacific Northwest, 1858-1900,"in Changing Habits: Women's Religious Orders in Canada, ed. Elizabeth Smyth (Ottawa: Novalis, 2007),156-58. Sister Mary James, Providence: A Sketch of the Sisters of Charity of Providence in the Northwest, 1856-1931 (Seattle: Sisters of Charity of Providence, 1931), 4-18. Marguerite Jean, “Tavernier, Emilie," in Dictionary of Canadian Biography, Vol. VIII (Toronto: University of Toronto Press, 1985),

24 Margaret McGovern, "Perspective on the Oblates: The Experience of the Sisters of Providence," in Western Oblate Studies 3, ed. Ray Huel (Edmonton: Western Canadian Publishers, 1994), 95.

25 This approach has inevitable limitations. I recognize that inspection reports are only one source of information about classroom practice but I would argue that they are sufficient, when the context is considered, to allow for tentative judgments about these schools and their academic programs. The peculiar administrative structures and legal arrangements under which the institutions operated and the powerlessness of provincial inspectors to influence change mean that any analysis similar to that of Curtis in the case of Canada West is impossible. See Bruce Curtis, True Government by Choice Men? Inspection, Education, and State Formation in Canada West (Toronto: University of Toronto Press, 1992). 
26 McGovern, "Perspective on the Oblates," 99.

27 Brown, Buck, Filteau, Survey, A 20. LAC, RG 10, vol. 8686, file 777/23-5-010, Report of Indian agent G.S. Lapp, March 1954; C. Pant.,Schmidt to H.W. McGill, 18 August 1939.

28 LAC, RG 10, fol. 8686, file 777/23-5-010, L. Waller inspection report, 2 Dec.

29 Ibid., L. Broughton inspection reports, 20 Jan. 1949, 28 Feb.1952; L.Waller inspection report, 2-3 October 1951.

30 Ibid., L. Broughton inspection reports, 19 Jan. 1949, 28 Feb. 1952; L. Waller inspection report, 2-3 Oct. 1951.

31 Ibid., L. Broughton inspection reports, 19 Jan.1949, 28 Feb. 1952; L. Waller inspection reports, 2-3 Oct. 1951, 2 Dec.1952; G. Berry inspection reports, 10 March 1953, 10 March 1954, 2 March 1955, 29 Feb. 1956.

32 Interview, Catherine McIntyre, Edmonton, Alberta, 10, 11 April 2003.

33 LAC, RG 10, vol. 8686, file 777/6-1-010, L. Waller inspection report, 2 Dec.1952; G. Berry inspection reports, 10 March 1953, 10 March 1954, 2 March 1955.

34 Ibid., L. Waller inspection report, 2 Dec. 1952; G. Berry inspection reports, 10 March 1953, 8 March 1954, 2 April 1955, 29 Feb./I March 1956, 1 Sep. 1957.

35 Ibid., G. Berry inspection report, 1 Sep. 1957.

36 Interview, Catherine McIntyre.

37 LAC, RG 10, vol. 8686, file 777/6-1-010, R.F. Davey to Regional Supervisor, Alberta, 25 March 1959.

38 LAC, RG 10, vol. 8614, file 777/1-13-010, pt.1, L.C. Hunter to Indian Affairs Branch, 8 March 1960.

39 LAC, RG 10, vol. 6367, file 762-5, pt. 1, R. Ferrier to D.C. Scott, 17 Jan.1924.

40 Brown, Buck, Filteau, Survey, A 18-19.

41 LAC, RG 10, vol. 8686, file 777/6-1-010, E.C. Stehelin inspection report, 13 March 1946; L. Broughton inspection reports, 24 March 1948, 13 Dec. 1949; L. Waller inspection report, 19, 20 March 1952; G. Berry inspection report, 9 April 1954.

42 Ibid., E.C. Stehelin inspection reports, 14, 15 March 1945, 13 March 1946, 29 April 1947; L. Broughton inspection reports, 24 March 1948, 14 Dec. 1949; L. Waller inspection report, 19, 20 March 1952.

43 Ibid., E.C. Stehelin inspection reports, 15 March 1945, 16 May 1947; L. Broughton inspection report, 14 Dec. 1949; L. Waller inspection reports, 19, 20 March 1952, 24, 25 Nov. 1952; G. Berry inspection report, 8 April 1954.

44 Ibid., L. Broughton inspection reports, 23 March 1948, 13 Dec. 1949; L. Waller inspection report, 19, 20 March 1952.

45 Ibid., E.C. Stehelin inspection report, 15 March 1945.

46 Ibid., E.C. Stehelin inspection report, 13 March 1946.

47 Ibid., E.C. Stehelin inspection report, 29 April 1947.

48 LAC, RG 10, vol. 6367, file 762-3, pt.1, G.S. Lapp to G.H. Gooderham, 13 Feb. 1950.

49 LAC, RG 10, vol. 8686, file 777/6-1-010, G. Berry inspection reports, 9 April 1954, 21 Feb. 1955, 26 April 1956.

50 LAC, RG 10, vol. 8684, file 701/1-13, Circular letter No. 16 to principals of residential and day schools from IAB, Edmonton, 10 Feb. 1960.

51 LAC, RG 10, vol. 8684, file 777/1-13-007, L.C. Hunter to Regional supervisor, Alberta, 4 May 1960.

52 LAC, RG 10, vol. 8684, file 777/25-1-007, H. Routhier to R.S. Davey, Superintendent of Indian Education, 25 July 1962.

53 LAC, RG 10, vol. 8684, file 131/25-1-762, H. Routhier to K. Gooderham, 12 March 1965.

54 LAC, RG 10, vol. 8684, file 701/25-1-11, Memo of D.M. Hopton, 18 July 1967. 
55 J. Donald Wilson, "From the Swinging Sixties to the Sobering Seventies," in Precepts, Policy and Process: Perspectives on Contemporary Canadian Education, eds., Hugh A. Stevenson and J. Donald Wilson (London, Ont.: Alexander, Blake Associates, 1977), 22.

56 Mary James, Providence, 61.

57 Nick Kach, "The Emergence of Progressive Education in Alberta," in Exploring Our Educational Past: Schooling in the North-West Territories and Alberta, eds., Nick Kach and Kaz Mazurek (Calgary: Detselig, 1992).

58 Pius XI, "Divini Illius Magistri" ("The Christian Education of Youth"), in Great Encyclicals, intro. William J. Gibbons (New York: Paulist Press, 1963), 54-55, 63.

59 Lora Ann Quincuez and Mary Daniel Turner, The Transformation of American Catholic Sisters (Philadelphia: Temple University Press, 1992), 6.

60 Elio Gambari, "Formation of Religious for the Apostolate Today," in Religious Life in the Church Today: Prospect and Retrospect, ed. Mother Mary Florence (South Bend, Indiana: University of Notre Dame Press, 1962), 83-4.

61 Patricia Wittberg, The Rise and Fall of Catholic Religious Orders: A Social Movement Perspective (Albany: State University of New York Press, 1994), 210-13.

62 Rosa Bruno-Jofré, "The Process of Renewal of the Missionary Oblate Sisters, 1963-1989," in Changing Habits, ed. Smyth, 249.

63 Grant, Moon of Wintertime, 234. 